Research Report No. 23/2013

\title{
Section 2(b)'s Other Fundamental Freedom: The Press Guarantee, 1982-2012
}

Jamie Cameron

Osgoode Hall Law School of York University, jcameron@osgoode.yorku.ca

Follow this and additional works at: http://digitalcommons.osgoode.yorku.ca/clpe

\section{Recommended Citation}

Cameron, Jamie, "Section 2(b)'s Other Fundamental Freedom: The Press Guarantee, 1982-2012" (2013). Comparative Research in Law of Political Economy. Research Paper No. 23/2013.

http://digitalcommons.osgoode.yorku.ca/clpe/270 


\section{OSGOODE}

OSGOODE HALL LAW SCHOOL YOR K U N I VERSITY

\section{OSGOODE HALL LAW SCHOOL}

Comparative Research in Law \& Political Economy

RESEARCH PAPER SERIES

Research Paper No. 23/2013

\section{Section 2(b)'s Other Fundamental Freedom: The Press Guarantee, 1982-2012}

Jamie Cameron

\section{Editors:}

Peer Zumbansen (Osgoode Hall Law School, Toronto, Director Comparative Research in Law and Political Economy)

John W. Cioffi (University of California at Riverside)

Leeanne Footman (Osgoode Hall Law School, Toronto, Production Editor)

Comparative Research in Law \& Political Economy 


\title{
Section 2(b)'s other fundamental freedom: the press guarantee, 1982-2012
}

\author{
Jamie Cameron*
}

\section{The early Charter legacy}

The Charter's thirtieth anniversary was a muted affair. Against the outline of its early landmarks, the Charter has now settled into the rhythm of Canadian life. The power to command, surprise, and shift the landscape may not have changed but today the Charter is workmanlike, seeming to busy itself more at the margins than at the core of debate about rights. Anniversary years like 2012 pay homage to the erstwhile days of blockbuster decisions as reminders of the journey to this point and dramatic steps taken along the way. A consensus draws around vitalizing decisions that gave life to the rights of the accused, gender equality, gay rights, and the rights of aboriginal peoples, among others. It is revealing that when the Charter's finest moments are on parade freedom of expression and the press are scarcely mentioned, much less heralded. Why these entitlements have not fired passions in the same way as others is thought provoking, and forms the backdrop to this reflection on s.2(b)'s journey from 1982 to 2012.

Section 2(b) identifies freedom of expression, including freedom of the press and other media of communication, as fundamental freedoms guaranteed by the Charter. ${ }^{1}$ To protect freedom is to pose a test of courage - the courage of a democracy, its communities and individuals. Section 2(b) of the Charter calls for fear and prejudice to be set aside in the name of freedom for all ideas, no matter how

\footnotetext{
*Professor, Osgoode Hall Law School. I would like to thank Cara-Marie O’Hagan for inviting me to participate in the Ryerson Law Centre's Conference, "Press Freedom in Canada: A Status Report on the $30^{\text {th }}$ Anniversary of the Charter of Rights and Freedoms", and also for her perceptive comments and feedback on an earlier draft of this paper. I make similar arguments about freedom of expression and the press under the Charter in a more detailed Article: see "A Reflection on Section 2(b)'s Quixotic Journey, 1982-2012" in J. Cameron \& S. Lawrence, eds., (2012), 58 S.C.L.R. (2d) 163-94.

1 Canadian Charter of Rights and Freedoms, part I of the Constitution Act, 1982, being Schedule B to the Canada Act 1982 (U.K.), 1982, c. 11 (the "Charter").
} 
fiercely or strenuously they should be opposed. Tolerance for the intolerable means that those who are disgruntled, objectionable and mean-spirited will offend us, including and especially those who are vulnerable, sensitive or fearful. Yet it is unavoidable that expressive freedom can only thrive when judgment of its exercise is suspended. Rather than condemn society to a fate of unrequited conflict and darkness, an open process of freedom is a mark of progress and a testament to democracy's essential humility. $^{2}$

Though the temptation to judge the message must be suspended, freedom is not absolute and nor is judgment absolutely suspended. The exercise of freedom can be judged and is subject to limits when it causes harm. In the case of expressive activity the link to harm can be difficult to show because words and opinions are more likely to change attitudes and influence views than to prompt immediate or violent action. That is why it is no easy task to pinpoint the moment when expression crosses the line and is no longer free because it has become dangerous enough to prohibit. When controversial or unpopular expression was at stake under the Charter, the Supreme Court adopted a risk-averse approach and invariably chose limits on expression over freedom. The question that s.2(b)'s early legacy raises is whether restrictions were upheld because harm was shown, or because expression like hate propaganda, obscenity and pornography, child pornography, tobacco advertising, defamation, and discriminatory messages offend mainstream sensibilities. This legacy leaves unclear whether freedom of expression is stronger than it was before the Charter.

Meanwhile, the relative insignificance of freedom of the press in this period raises other concerns. It is puzzling that there have only been a few Supreme Court decisions on the press, and troubling that it remains uncertain whether freedom of the press is an independent entitlement, with distinctive

2 The hall mark of this humility is the power of self-government, with its expectation and aspiration that members of the community will participate, collectively and equally, in social and political decision making, and its faith that democratic society will evolve through an open process of engagement and debate. 
content, or is subsumed in expressive freedom. This jurisprudence, which is modest by any standard, pivots on the Charter status of newsgathering. At key moments in s.2(b)'s formative period the Court not only refused to grant this core function constitutional status but in doing so skirted s.2(b) altogether. Engaging the guarantee is an obvious first step in granting the press protection under the Charter.

If the Supreme Court's early jurisprudence has not met expectations, still it should not be viewed as an unvarnished disappointment. There is a crowning achievement in the first thirty years of the Charter, and that is the open justice principle. With little hesitation, the Supreme Court adopted a confident and vigilant approach to measures that excluded the press and public from judicial proceedings or imposed publication bans to prohibit reporters and others from disclosing information learned in such proceedings. The press played a leading role in developing this constitutional concept of transparency, which is distinctive because it blends s.2(b)'s twin expression and press guarantees together. The Charter jurisprudence on open justice stands apart but should not be thought of as singular; to the contrary, the Supreme Court's approach to open justice offers a model for all of s.2(b).

The Charter's thirtieth anniversary is a checkpoint, an opportunity to take stock of s.2(b)'s journey to date. Though a broader reflection would examine the Supreme Court's conception of fundamental freedoms - including freedom of religion, assembly and association, as well as expression and the press - the focus here is on freedom of the press. A short introduction to expressive freedom under the Charter provides a preface to that discussion. In turning to the press, the central concern which emerges is the Supreme Court's avoidance of s.2(b) and its reluctance to grant newsgathering activities status under the Charter. Insisting that the press can be protected in other ways is unconvincing in the face of the Court's unwillingness to engage the Charter's explicit guarantee of a free press. At the same time and as noted, the open justice principle muddles this narrative by providing a 
shining example of s.2(b)'s promise. By demonstrating how the guarantee's freedoms can be protected when expression and the press work in tandem, the open justice jurisprudence to some extent offsets the newsgathering cases. Looking to the future, the Supreme Court should harmonize the disparate strands of the s.2(b) jurisprudence and, in particular, should apply the open justice methodology to questions of expressive and press freedom. As for the press, two obstacles stand in the way of robust protection for this freedom: one is theoretical and calls for a concept that explains the constitutional status of the press; the other is definitional and as such seeks a conceptual answer to the challenge of identifying who the press is at this moment in time. Addressing these obstacles will not only enable but also require the Supreme Court to protect the press and its newsgathering activities under s.2(b). If and when that happens, the status of the press under s.2(b) should be much improved at the Charter's next checkpoint.

\section{Freedom of expression: a seesaw of rights and limits}

Freedom of expression is the dominant force in the s.2(b) jurisprudence, and interpreting that guarantee has been the Supreme Court's primary concern since 1982. Meanwhile, it has not been well understood that freedom of the press is an independent guarantee, and perhaps for that reason the Court's concept of this entitlement is not well developed. Despite the asymmetry between s.2(b)'s two clauses, a scan of expressive freedom under the Charter can offer insight into the Court's view of the press. $^{3}$ In considering expressive freedom, the Supreme Court adopted a definition of the right that is beyond reproach, and then turned away from it in upholding restrictions on expressive activities. In like manner, and despite supporting the role of a free press in democratic governance, the Court has refused to engage the press guarantee under s.2(b).

\footnotetext{
${ }^{3}$ The text itself treats the two differently: s.2(b) guarantees "freedom of thought, belief, opinion and expression" and then adds,"including the press and other media of communication" (emphasis added); supra, note 1.
} 
In the space of thirty years the Supreme Court has embedded a fundamentally ambivalent conception of expressive freedom in the jurisprudence. To explain, this ambivalence is grounded in the Charter's logic, which sets up an equation, or seesaw, between the guaranteed rights and freedoms on one side, and the countervailing concept of reasonable limits on the other. In terms, s.1's idea of reasonable limits allows Charter violations to be "saved", or upheld, when it is justifiable in the broader interests of the democratic community. Though the equation seeks equilibrium between the two sides, the Charter mandates that the guarantees prevail unless the state can prove under s.1 that limiting its rights and freedoms is demonstrably justified. ${ }^{4}$

On the entitlement side of the equation, the Supreme Court was uncompromising in defining the scope of expressive freedom. In interpreting s.2(b), the judges resisted the temptation to limit the guarantee and consistently refused to exclude offensive and objectionable expression from the Charter. Instead of passing judgment on the activities at stake the Court declared, in principle, that s.2(b) protects all content of expression without regard to its merit, value, or virtue. ${ }^{5}$ Treating expression initially as equal under s.2(b) took courage because it meant that objectionable expression, such as hate propaganda, pornography, and child pornography, would be protected by the Charter. ${ }^{6}$

\footnotetext{
${ }^{4}$ Section 1 states: "The Canadian Charter of Rights and Freedoms guarantees the rights and freedoms set out in it subject only to such reasonable limits prescribed by law as can be demonstrably justified in a free and democratic society" (emphasis added); Charter, ibid.

${ }^{5}$ Irwin Toy Ltd. V. Quebec (Attorney General), [1989] 1 S.C.R. 927, at 968 (stating that "[f]reedom of expression is entrenched ... so as to ensure that everyone can manifest their thoughts, opinions, beliefs, indeed all expressions of the heart and mind, however unpopular, distasteful or contrary to the mainstream").

${ }^{6}$ Under this view of expressive freedom the Supreme Court granted s.2(b)'s protection to hate propaganda: $R$. $v$. Keegstra, [1990] 3 S.C.R. 697; obscenity and pornography: R. v. Butler, [1992] 1 S.C.R. 452; and child pornography: R. v. Sharpe, [2001] 1 S.C.R. 427.
} 
It would be difficult to overstate the importance of this development in the s.2(b) jurisprudence. The Court's commitment to equality between ideas, or "content neutrality", rests on the assumption that whenever the state singles certain messages out for restriction it necessarily engages in a form of discrimination, and an act of censorship. ${ }^{7}$ Generally speaking, any interference with expressive freedom prima facie violates s.2(b) and will only be permitted when the evidence supports reasonable limits under s.1. ${ }^{8}$ In embracing a broad and open process of freedom the Court accepted it both as right in principle and as imperative in democratic terms that undesirable messages have the same voice, the same place in the public domain, and the same stake in the debate as mainstream points of view.

Unfortunately, that concept of freedom was fleeting and the Court's discomfort with the implications of protecting freedom quickly took flight under s.1. There, against the proposition that expressive activity is protected unless harm can be shown, it turned out that the evidence of harm in many instances was either incomplete or inconclusive. Faced with the prospect of protecting meanspirited, hurtful and unpleasant expression, the Court chose to abandon s.2(b)'s hard-earned concept of content neutrality. Instead of asking whether expressive activity was harmful enough to be limited, it developed a methodology that considered whether the content was valuable enough to be protected. After being rejected from s.2(b) as inappropriate and in essence a tool of censorship, value paradoxically became the pivot for the s.1 analysis. This "core values" approach allowed the Court to lower the standard for limits on "low value" expression and uphold restrictions on a range of controversial

\footnotetext{
${ }^{7}$ lbid. at 969 (stating that "[w] cannot [] exclude human activity from the scope of guaranteed free expression on the basis of the content or meaning being conveyed," and adding that "if the activity conveys or attempts to convey a meaning it has expressive content and prima facie falls within the scope of the guarantee").

${ }^{8}$ Irwin Toy proposed a two-step test under s.2(b): step one asks whether the activity is expressive, as a matter of definition; and step two applies the "purpose-effect" distinction to determine whether there is an infringement requiring justification under s.1. Ibid. at 978-9 (summarizing that test).
} 
activities. ${ }^{9}$ The Charter's protection was not withheld in these cases because the evidence could show in empirical terms that expression caused but because the Court found that the messages in question were not valuable. In the briefest of accounts, this then is the genesis of a methodology that rests on a fundamental incompatibility between its underlying assumptions about expressive freedom and its permissible limits. This methodology not only rendered the jurisprudence incoherent but also made a mockery of s.2(b)'s concept of freedom. ${ }^{10}$

In overview, an inventory of the first thirty years reveals that decisions upholding limits on expressive freedom outstrip those protecting the right by a margin of about two to one. Whether that ratio is out of step in comparison to other Charter guarantees, what stands out is the Supreme Court's willingness to bless restrictions on difficult and marginal expressive activity. Under s.2(b) it adopted a principled definition of expressive freedom which was open and egalitarian, and as such guaranteed all points of view a right of access to the process of discussion and debate. Yet the Court lacked strength of conviction and the gesture did not count for much once s.1 grafted a value-based analysis onto s.2(b)'s concept of freedom. The Court's lack of self-consciousness about this contradiction, along with its willingness to turn its back on the meaning of freedom under s.2(b), can only be seen as profound compromises. In broad terms the pattern in the press cases would be similar: the Court gave a free press strong endorsement in the abstract but would not grant newsgathering, its core function, status under s.2(b).

\footnotetext{
${ }^{9}$ These include, among others, hate propaganda: Keegstra, supra, note 6; discriminatory messages: Canada (Human Rights Commission) v. Taylor, [1990] 3 S.C.R. 892; obscenity and pornography: Butler, supra, note 6; child pornography: Sharpe, supra note 6; tobacco advertising: Canada (Attorney General) v. JTI-Macondald Corp., [2007] 2 S.C.R. 610; and defamation under the Criminal Code: R. v. Lucas, [1998], 1 S.C.R. 439.

${ }^{10}$ For a longer comment see J. Cameron, “A Reflection on Section 2(b)'s Quixotic Journey, 1982-2012" in J.Cameron \& S. Lawrence, eds., (2012), 58 S.C.L.R. (2d) 163-94.
} 


\section{The press, newsgathering, and the Charter}

The Supreme Court's press jurisprudence has two branches: while one deals with issues that relate exclusively to the press, the other addresses questions that involve overlap between press and expressive freedom. While the Court supported the entitlement when the two were joined in the open justice setting, it was more reluctant to do so when newsgathering was at stake on its own. ${ }^{11}$ That question was squarely posed on two occasions, several years apart. In 1991, the CBC sought relief under the Charter from search warrants seeking access to film footage that belonged to the broadcaster. ${ }^{12}$ Then in 2010, reporters from two national newspapers claimed a privilege to protect the identity of confidential newsgathering sources. ${ }^{13}$ Both times the Court proclaimed its support for a free press but refused to engage s.2(b).

The 1991 search warrant cases gave the Supreme Court the opportunity to address the Charter status of the press. At different times and places the $\mathrm{CBC}$ had attended demonstrations to gather news and report these events to the public. To advance their investigation, law enforcement officers sought access to the CBC's newsgathering material after the fact, which included raw footage as well as clips that had been broadcast. In challenging the warrants, the CBC maintained that the warrants violated its rights under s.2(b) and argued that to protect the integrity of newsgathering the threshold had to be substantially raised in the case of any search of the press.

\footnotetext{
${ }^{11}$ The law of defamation also engages expressive freedom and press interests, and though it is beyond the scope of this Article it is worth noting that there, as well, the Supreme Court rejected a Charter solution in re-thinking the way the common law balances the protection of reputation against expressive and press freedom. See, e.g.,Hill $v$. Church of Scientology, [1995] 2 S.C.R. 1130; WIC Radio Ltd. V. Simpson, [2008] 2 S.C.R. 420; and Grant v. Torstar, [2009] 3 S.C.R. 640.

${ }^{12}$ Canadian Broadcasting Corp. v. Lessard, [1991] 3 S.C.R. 421, at 436; Canadian Broadcasting Corp. v. New Brunswick (AG), [1991] 3 S.C.R. 459.

${ }^{13}$ R. v. National Post, [2010] 1 S.C.R. 477; The Globe and Mail v. Canada (AG), [2010] 2 S.C.R. 592.
} 
The Supreme Court did not hesitate to acknowledge the vital role of a free press and its connection to democratic governance. ${ }^{14}$ But rather than address the constitutionality of the warrants under s.2(b) it deflected the issue to s.8 of the Charter, which prohibits unreasonable search or seizure. ${ }^{15}$ Doing so enabled the judges to diffuse the direct violation of press rights and re-cast it under s.8, where it could be treated in much the same way as any other search. Instead of making the warrants contingent on conditions or requirements being met, the Court identified press-specific variables that should be taken into account to determine the reasonableness of the search. ${ }^{16}$ In upholding the search warrants in both cases, the Court held that the CBC's newsgathering was not compromised, in large part because the footage had already been broadcast and the CBC therefore could not claim that the material was private or confidential. ${ }^{17}$ In such circumstances, the CBC had no further legitimate interest in withholding this footage, and its refusal to release it to the police accordingly constituted an unreasonable demand for accommodation.

\footnotetext{
${ }^{14}$ See e.g. New Brunswick, supra, note 12, at 475 (stating that the media "have a vitally important role to play in democratic society" and that it is the media which, "by gathering and disseminating news, enable members of our society to make an informed assessment of the issues which may significantly affect their lives and well-being").

${ }^{15}$ Section 8 states: "Everyone has the right to be secure against unreasonable search or seizure"; Charter, supra, note 1.

${ }^{16}$ The Court generated a checklist of nine variables, four of which reference the circumstances of the press: the first indicates the need to balance the demands of law enforcement against the privacy rights of the press; the second considers whether the information is available from other sources and whether reasonable efforts to obtain it have been taken and exhausted; the third indicates that the warrant will generally be available when the information has been disseminated; and the fourth states that any search of premises should minimize the interference with press operations. New Brunswick, supra, note 12, at 481.

${ }^{17}$ Lessard, supra, note 12, at 446-7 (stating that "the crucial factor is that, prior to the application for the warrant, the media had broadcast portions of the videotape ... on two occasions, both in French and English" and that "once the media have published the gathered information, that information then passes into the public domain"). Even so, the police seized five videotapes, four of which contained raw footage that had never been broadcast. Ibid. at 441 .
} 
Only one member of the Court realized what was at stake and spoke up for freedom of the press. ${ }^{18}$ Justice McLachlin J., who is now the Chief Justice of Canada, wrote a dissent which held that the state's interference with newsgathering activities violated s.2(b) and could not be deflected to s.8 and its criteria for reasonable search. McLachlin J. gave a vigorous account of press freedom in Canada, recognized that it is the prospect of interference with newsgathering that creates a chilling effect on the press function, and rejected the suggestion that the press and public should be governed by the same standards for search. ${ }^{19}$ To protect newsgathering she proposed a press-specific Charter standard that would make search warrants contingent on certain conditions being satisfied. ${ }^{20}$ She would have invalidated these warrants because the police did not show that the evidence being sought from the $\mathrm{CBC}$ was unavailable from other sources, or explain why it was necessary to search a member of the press. Justice McLachlin rejected a presumption in favour of law enforcement goals, and stated that the press should only be searched when the warrants explain why access to the evidence is more important than freedom of the press.

The CBC search cases are troubling at several levels. In sidelining s.2(b), the Supreme Court took the Charter's explicit guarantee out of the calculus. Despite the celebratory references, the Court's endorsement of a free press was abstract and represented little more than a gesture. The resulting gulf between an abstract conception and a commitment to freedom is reminiscent of the pattern in the

\footnotetext{
${ }^{18}$ La Forest J. wrote of the need to protect newsgathering, because " $t \mathrm{t}$ ]he press should not be turned into an investigative arm of the state", ibid. at 432 , but upheld the warrants on the facts of the cases.

${ }^{19}$ In her words, "[t]he history of freedom of the press in Canada belies the notion that the press can be treated like other citizens or legal entities when its activities come into conflict with the state". Ibid. at 450.

${ }^{20}$ Specifically, she would have required the police to show that a search warrant is necessary because there are no alternative sources for the information required, to explain why the importance of the search outweighs the damage caused by infringing freedom of the press, and to demonstrate that the search will interfere with press freedom as little as possible. Ibid. at 455.
} 
expression cases, where the Court supported the principle of freedom but surrendered it to the concept of reasonable limits under s.1. In this instance, the Court focused on the question of search at the expense of freedom of the press and, in doing so, placed newsgathering at the mercy of s.8's malleable standard of reasonableness. Despite acknowledging the need for vigilance when the press is searched, the Court refused to impose conditions on police access to newsgathering materials. Perhaps most disappointing of all was the Court's suggestion that there is little or no difference between the press and members of the public. In scolding that the $\mathrm{CBC}$ ought to be as willing to volunteer its evidence as any citizen the Court missed the point that the press cannot discharge its democratic responsibilities unless it is free from interference from the state and independent in its newsgathering activities. ${ }^{21}$

Years would pass before the Court considered the Charter status of newsgathering again and when it did, the issue arose in the high stakes setting of confidential newsgathering sources. Twice in the same year the Supreme Court was asked to protect a source when investigative reporters from the National Post and Globe \& Mail received damaging information about explosive political scandals respectively, Shawinigate and the Quebec sponsorship scandal - in exchange for a promise of confidentiality. ${ }^{22}$ In deciding whether to protect the journalist's source, the Supreme Court was once again invited to engage the Charter and grant newsgathering constitutional status under s.2(b). Following the pattern of the jurisprudence, the Court was quick to confirm its commitment to freedom of the press. Both decisions acknowledged the importance of confidential sources, the role they play in

\footnotetext{
${ }^{21} \mathrm{lbid}$. at 446 (stating that "all members of the community have an interest in seeing that crimes are investigated and prosecuted" and suggesting that "the media might even consider voluntarily delivering their videotapes to the police"). See also New Brunswick, supra, note 12, at 477 (stating that "[t]he media, like any good citizen, should not be unduly opposed to disclosing to the police the evidence they have gathered ...."; emphasis added).

${ }^{22}$ National Post and Globe \& Mail, supra, note 13.
} 
newsgathering, and the vital link between newsgathering and democratic functions. ${ }^{23}$ Despite doing so, the Court resisted a press-specific solution under the Charter and claimed, instead, that the general rule of evidence at common law - which recognizes a privilege for confidential relationships in some circumstances - is sufficient to safeguard the constitutional interests at stake. ${ }^{24}$

The slightly re-modelled common law rule which emerged from these cases may afford confidential newsgathering sources protection in many circumstances. Even so, there are significant differences between a Charter solution, which explicitly constitutionalizes newsgathering and sets a high threshold for the violation of confidential newsgathering relationships, and a common law standard which nudges a generic rule for privilege in a more press-protective direction. It is the difference between a common law regime which places the onus on a journalist to prove that her source should be protected, and a constitutional framework which protects the relationship, and places the burden on anyone seeking disclosure to justify the violation of a confidential relationship pursuant to stringent Charter-specific requirements. ${ }^{25}$

\footnotetext{
${ }^{23}$ See e.g., National Post, ibid. at para. 41. See also paras. 30, 31 and 33 (recognizing that "[t]he appellants and their experts make a convincing case that unless the media can offer anonymity in situations where sources would otherwise dry-up, freedom of expression in debate on matters of public interest would be badly compromised" and "[i]mportant stories will be left untold, and the transparency and accountability of our public institutions will be compromised to the public detriment").

${ }^{24} \mathrm{Ibid}$. at paras. 54 and 64 (commenting, additionally, on the common law standard, at para. 64 that "[t]he public interest in free expression will always weigh heavily in the balance" and noting that "[w]hile confidential sources are not constitutionally protected, their role is closely aligned with the role of 'freedom of the press and other media of communication', and will be valued accordingly"; emphasis in original).
}

${ }^{25}$ For a longer discussion of the common law Wigmore rule of privilege and the Charter, as well as an analysis of Shawinigate and the newsgathering function, see J. Cameron, "Of Scandals, Sources and Secrets: Investigative Reporting, National Post and Globe and Mail", in J. Cameron \& B. Ryder, eds., (2011), 54 S.C.L.R. (2d) 232-72. 
By suggesting that the press enjoys particular rights and privileges, s.2(b) entrenches a form of exceptionalism. As the newsgathering cases show, the Supreme Court is sympathetic to freedom of the press but uncomfortable with the implications of constitutionalizing those sympathies. At root, the problem in these cases was that the newsgathering activities could not be protected without creating exceptions for the press, or exemptions from the rules that ordinarily apply. The demand for special treatment put the Court on guard because any claim that the press is above the ordinary law conflicts with the rule of law and the primordial principle that all are equal in the eyes of the law. Though s.2(b)'s exceptionalism is grounded in a democratic conception of the press, the Court's skepticism reflects legitimate concerns about the legitimacy of singling this class out for special treatment under the Charter. Absent a theory to bridge that gap, the Court's willingness to treat the press somewhat differently, but not to formalize that difference in constitutional doctrine, is not so surprising.

\section{Open justice: a section 2(b) model}

A fair summary of the s.2(b) jurisprudence points to significant victories in some cases, as well as to the Supreme Court's steady recognition of the critical role expressive and press freedom have played in our democratic tradition. Less positively, it had few qualms in discounting freedom principles at the point of decision. As discussed, the Court allowed restrictions on controversial expression by designating the messages as low in value and distant from s.2(b)'s core. Meanwhile, in the context of search warrants and confidential sources, the jurisprudence failed to recognize a constitutional entitlement for the press or to protect newsgathering activities from interference by the state.

One part of the narrative remains to be told, and it concerns the area in which the Court has given s.2(b) singular protection, and that is on open justice or open court questions. This jurisprudence unquestionably represents the pinnacle of success for s.2(b) in the first thirty years of the Charter. The 
issue in these cases concerns judicial proceedings which are closed to the public, and publication bans which prohibit the disclosure of information that is revealed in the course of such proceedings. In a series of cases the Supreme Court developed and applied a methodology that made it difficult to impose publication bans or close proceedings to the public. Not only did the Court develop a customized standard to deal with this issue, in applying that standard the judges made it clear that any limits that were permitted would have to be evidence-based. ${ }^{26}$

This branch of the jurisprudence is distinctive in part because it rests on a synergy between s.2(b)'s expressive and press freedoms. Most of the key decisions were either initiated by or involved media litigants who played a leadership role in bringing open justice forward under the Charter. The Supreme Court validated the central role of the press as the public's agent in advancing s.2(b)'s goals of transparency and accountability in matters relating to the justice system. In addition, it located the public's right to know about and comment on such matters at the core of s.2(b) and its vital link to democratic process.

Although Dagenais v. $C B C$ is rightly regarded as the watershed, the closed court decision stands out for its insight on s.2(b)'s press guarantee. ${ }^{27}$ When a judge closed his courtroom for about twenty minutes during sentencing in a sexual assault trial, the violation of open justice was relatively brief. Though he closed the court to protect those involved, including the young victims, the Supreme Court responded with a strict and uncompromising view of open justice. ${ }^{28}$ Justice La Forest developed the links

\footnotetext{
${ }^{26}$ The key cases are Nova Scotia v. MacIntyre, [1982] 1 S.C.R. 175 (access to search warrants); Edmonton Journal v. Alberta (AG), [1989] 2 S.C.R. 1326 (publication ban); Dagenais v. CBC, [1994] 3 S.C.R. 835 (publication ban); CBC v. New Brunswick (AG), [1996] 3 S.C.R (closed courtroom). 480; R. v. Mentuck, [2001] 3 S.C.R. 442 (publication ban); and Re Vancouver Sun, [2004], 2 S.C.R. 332 (closed hearing).

${ }^{27}$ Dagenais, ibid.

${ }^{28}$ New Brunswick, supra, note 26.
} 
between public engagement and democratic process that are protected by s.2(b) by emphasizing the "democratic function of public criticism of the courts" and confirming the Court's view that "it is difficult to think of a guaranteed right more important to a democratic society than freedom of expression". ${ }^{29}$ Having established that the transparency and accountability of the justice system are core values, he turned to the press and tied the newsgathering function to the public interest in access to information about the justice system.

Thus he declared that "[t]he full and fair discussion of public institutions, which is vital to any democracy, is the raison d'être of the $5.2(b)$ guarantee," and added that "[d]ebate in the public domain is predicated on an informed public, which is in turn reliant on a free and vigorous press" ${ }^{30}$ He also emphasized that the press cannot inform the public and equip it to discharge its democratic responsibilities without having access to courts and court proceedings. The synergy between the public and press entitlements reached full momentum in his announcement that "freedom of the press not only encompasse[s] the right to report news and other information, but also the right to gather this information". ${ }^{31}$ The strength of this principle was re-inforced by the Court's stern admonition that exceptions to open justice must be evidence-based and satisfy a strict standard of justification.

The Supreme Court's commitment to open justice continued to evolve and reached its apex in a case involving the Vancouver Sun, a secret hearing under the post 9/11 terrorism laws, and the Air India

29 Ibid., at paras. 17 and 19 (also stating, at para. 18, that "[t]he freedom of individuals to discuss information about the institutions of government, their policies and practices, is crucial to any notion of democratic rule").

${ }^{30}$ Ibid. at para. 23.

31 Ibid. at para. 24. In doing so he relied on his concurring opinion in Lessard, supra, note 12 and its conclusion that "the freedom to disseminate information would be of little value if the freedom under s.2(b) did not also encompass the right to gather news and other information without undue government interference;" (emphasis in original). 
trial. $^{32}$ There, a reporter discovered by chance that while the Air India trial was taking place in an open courtroom an investigative hearing was being held behind closed doors in another part of the courthouse. Were it not for the fortuity of that discovery, that hearing might have forever remained a secret. Against the compelling interest in investigations aimed at preventing and punishing acts of terrorism, the Supreme Court found the danger of secret judicial proceedings even more threatening, because of their serious implications for the integrity of justice. ${ }^{33}$ As a result, the Court held that the presumption of open access to judicial proceedings applied even to sensitive investigative hearings under Parliament's anti-terrorism laws. According to Vancouver Sun, the proceedings could only be closed if the state rebutted the presumption with evidence showing that it was imperative to the investigation that the hearing be conducted in camera, or behind closed doors. The investigative hearing was one of the most controversial provisions at the time Canada's anti-terrorism provisions were adopted. In imposing a constitutional requirement of openness the Court made it difficult, if not close to impossible, for the government to conduct this kind of investigative hearing.

At first impression it is difficult to square open justice with the newsgathering decisions on search warrants and confidential sources. It is especially indicative that the Court expressly constitutionalized newsgathering when open justice was at stake, and then refused to engage s.2(b) when the issue arose in the journalist source cases. That said, its responsiveness to claims that sounded

\footnotetext{
${ }^{32}$ Re Vancouver Sun, supra, note 26. The other key open justice decisions from this era are R. v. Mentuck, supra, note 26; and R. v. O.N.E., [2001], 3 S.C.R. 478, both of which concerned judicial publication bans.

${ }^{33}$ The Court's commitment could to open justice could hardly have been stronger. See, ibid. at para. 26 (stating that " $[t]$ he open court principle is inextricably linked to the freedom of expression protected by s. $2(b)$ of the Charter and advances the core values therein"; that [t]he freedom of the press to report on judicial proceedings is a core value"; that, "[e]qually, the right of the public to receive information is also protected by the constitutional guarantee of freedom of expression"; that "[t]he press plays a vital role in being the conduit through which the public receives that information regarding the operation of public institutions"; and, "[c]onsequently," that "the open court principle, to put it mildly, is not to be lightly interfered with").
} 
in access to justice drew strength from the synergy between s.2(b)'s twin freedoms, and open justice's pedigree in the common law tradition. First, and despite the close involvement of the press, the open justice principle takes its cue from s.2(b)'s guarantee of expression. In the Court's view, that principle serves public interests and belongs to members of the public, as members of a democratic community who have a direct interest in access to information bearing on the integrity of the justice system. ${ }^{34}$ Transparency and accountability in the public interest are dominant themes, and help to explain the Court's willingness to support the press and media in this context but not in others.

The same values were also at stake when the press sought protection for newsgathering and investigative reporting practices. There, however, the claims took the form of a demand for special treatment through an exemption from the usual rules for search and a privilege to protect a source by withholding vital information. It seemed, though, that rather than preserve its status as an agent of the public the press was seeking to protect its own interests in these instances. Though a theory could have forged the link between newsgathering, independence from the state, transparency and accountability, and the public interest, what the Court saw instead was a claim for preferred treatment. By contrast, open justice could be enforced without giving the press special recognition under the Charter.

Common law tradition also explains why the Supreme Court's response to open justice and investigative newsgathering was so different. The pedigree of the open court principle was established long before the Charter created constitutional protection for freedom of expression and the press. It is a creation of common law which evolved over the centuries and is vitally linked to the fairness, integrity,

\footnotetext{
${ }^{34}$ The Court began to develop this view in Edmonton Journal v. Alberta (AG), supra, note 26.
} 
and legitimacy of the justice system. ${ }^{35}$ From that perspective openness is not per se a press entitlement but has its roots in common law's recognition that the integrity of justice depends, in large part, on the transparency of the system. This principle is deeply embedded in the jurisprudence and, despite derogations under statutory provisions and common law doctrine, is bedrock in the Anglo-Canadian system of justice. Tradition and a concept of openness as a public entitlement enabled the Court to single this principle out for Charter protection without addressing the status of the press under s.2(b).

Regrettably, the open justice principle has been set back in a few recent Supreme Court decisions and it is unclear, at present, what the future holds in store. ${ }^{36}$ Rather than retreat from principle and a Charter methodology that sets a positive example for s.2(b), the Court should regard its open justice precedents as a model. Specifically, the attachment to principle, creation of a sound methodology, and principled demand for evidence-based limits are hallmarks of this jurisprudence which could and should be followed in other branches of s.2(b).

\section{The press: in its own right under the Charter}

Section 2(b)'s journey to this point can be thought of as a quixotic combination of zigs and zags, victories and disappointments, and pronouncements of principle which have been brushed aside to

\footnotetext{
${ }^{35}$ The Court first celebrated the values that attach to openness in MacIntyre v. Nova Scotia, where Dickson CJC's majority opinion laid the groundwork for the Charter jurisprudence; supra, note 26. Famously, he stated, at 185, that "covertness is the exception and openness the rule" and commented further that "[p]ublic confidence in the integrity of the court system and understanding of the administration of justice" are fostered by openness". At 189 he declared that "[t]he curtailment of the traditionally uninhibited accessibility of the public to the working of the courts should be undertaken with the greatest reluctance".

${ }^{36}$ The setbacks include Toronto Star Newspapers v. Canada (Attorney General), [2010] 2 S.C.R. 721 (upholding a statutory publication ban on bail hearing proceedings); CBC v. Canada (Attorney General), [2011] 1 S.C.R. 65 (concerning press access to evidence); and CBC V. Canada (Attorney General), [2011] 1 S.C.R. 19 (access to courthouse premises).
} 
accommodate limits on freedom. In the case of the press, particular obstacles stand in the way and must be addressed. One is the lack of a theory or set of rationales which speak to the role of the press; realistically, the perception that special treatment and exemptions are the issue will not change until it is established under s.2(b) that the press serves distinctive democratic purposes and has constitutional status for that reason. The second concerns a definition of the press, which has been a challenge before but never more than at the present.

At least in the abstract the Supreme Court has consistently demonstrated that it understands the value of a free press. Despite doing so it has balked when asked to enforce entitlements under s.2(b)'s explicit guarantee. Rather than engage the guarantee, the Court has sidestepped s.2(b) and proclaimed that it is able to accommodate press interests in other ways. In doing so the Court has processed its apprehension about the implications of constitutionalizing newsgathering activities in open and vocal terms. ${ }^{37}$ That apprehension makes it incumbent on those who support Charter protection for the press to allay those concerns.

Some preferential or distinctive treatment is necessary to enable the press to discharge its democratic responsibilities. The press function is directly linked to democratic governance because it provides the means for the public to hold government and other sources of power, whether corporate, institutional or individual, up to scrutiny. The kind of transparency that promotes accountability can only be achieved through robust reporting and commentary by a press that operates free from government

\footnotetext{
${ }^{37}$ See e.g., National Post, supra, note 13, at Ibid. at paras. 37-41 (explaining why the constitutional model should be rejected and emphasizing, in particular, that newsgathering could not be constitutionalized on this issue without creating expectations for other techniques - such as checkbook journalism - and claiming that to protect "a heterogeneous and ill-defined group of writers and speakers" would "blow a giant hole in law enforcement and other constitutionally recognized values such as privacy"; ibid. at para. 40 ).
} 
interference and functions independent of the state. This function is distinctive and institutional in nature, and cannot be served unless newsgathering is free from interference by the state. The constitutional status of the press is grounded in a function that recognizes transparency and accountability as core principles of our democratic tradition, and looks to the press as an agent of the public in preserving and protecting those values.

To its credit the Court had no difficulty with this concept on openness questions, but did not respond the same way in the newsgathering cases. There, it failed to grasp the need for the press to be scrupulously independent from the state in its newsgathering function. Co-opting the press as an arm of the government in the investigation of crimes undermines its authority as an investigative institution in its own right. To discharge its own democratic responsibilities the press must have control over its newsgathering material; its capacity for reporting in the public interest will otherwise be compromised. Along similar lines, investigative reporting depends on access to confidential sources; although the Court recognized the role of sources and acknowledged that journalists must be able to protect their sources, it failed to grasp in systemic terms that compelling a journalist to disclose a source - including the threat of forcing disclosure - fundamentally undermines the newsgathering function.

The integrity of the newsgathering process must be recognized and protected by the Charter. Rather than address the issue through s.8 or the common law, the focus should be on s.2(b) and should take the form of a presumption against interference with newsgathering. A principled approach would require judges to find a violation of s.2(b) when a search warrant is issued or disclosure of a confidential source is sought and to set a high evidentiary threshold of justification for any derogation from freedom of the press. It is simply a matter of adopting the open justice methodology and applying it to these issues. Under this approach derogations would be permissible under s.1, but only under a standard for 
reasonable limits that is designed to protect press freedom. This approach would grant newsgathering constitutional status and restrict interferences to exceptional circumstances where a compelling case for access to newsgathering materials has been made.

A second problem concerns the press itself, and the way technology has democratized the gathering, dissemination and sharing of information. Defining the press was not a significant issue in the first thirty years of the Charter when the institutional press was actively engaged in much of the s.2(b) jurisprudence. Conventional conceptions of the press have been destabilized in recent years by transformative technological change. This change has eroded the boundary between the institutional press and journalism professionals, and an undifferentiated group who may exercise their right of expressive freedom in ways that overlap with, mimic, or claim to engage a press function. Yet there are consequences for s.2(b) if newsgathering and the dissemination of news are no longer the exclusive precinct of the institutional press. In such circumstances, the question that demands urgent attention is whether a constitutional concept of the press is sustainable at this point in time, or must give way - in the face of technology's equalizing consequences - and fold press interests into the general guarantee of expressive freedom. To avoid that prospect it is incumbent, once again, on those who seek constitutional status for the press to make the case for an independent Charter guarantee that stands apart from, and is protected in different ways than, expressive freedom.

To survive and claim its own space under the Charter and shift the narrative at the Charter's next checkpoint, the press guarantee must meet this challenge: to avoid being collapsed into expressive freedom, s.2(b)'s other fundamental freedom must accommodate technological change in a way that preserves continuity with the democratic purposes and responsibilities of a free press. 